Volume and Issues Obtainable at Center for Sustainability Research and Consultancy
Journal of Business and Social Review in Emerging Economies
ISSN: 2519-089X \& ISSN (E): 2519-0326
Volume 7: Issue 4 December 2021
CSRᄃ
Journal homepage: www.publishing.globalcsrc.org/jbsee

\title{
Application of Human Rights Laws in Pakistan: A study with reference to International Bill of Human Rights
}

\author{
*Amjad Hussain, Assistant Professor, Department of Law, Islamia University Bahawalpur, \\ Pakistan \\ Muhammad Arif Saeed (LLM), Lecturer, Department of Law, The Islamia University of \\ Bahawalpur, Pakistan \\ Shahzada Aamir Mushtaq, Doctoral candidate at School of Law and Economics, Zhengzhou \\ University, Henan Mainland, China
}

*Corresponding author's email: ahpanwar@iub.edu.pk

\begin{tabular}{l}
\hline ARTICLE DETAILS \\
\hline History \\
Revised format: Nov 2021 \\
Available Online: Dec 2021 \\
\hline Keywords \\
International Law, Human \\
Rights, International \\
Human Rights, \\
Human Rights \\
Law, International \\
Conventions, Pakistan.
\end{tabular}

JEL Classification

K38, 015

\begin{abstract}
Purpose: The present paper explores the efforts of Pakistan regarding application of Human Rights Laws. At first, the research explains the main Human Rights declarations and covenants and then their incorporation into Pakistani laws has been described.

Design/Methodology/Approach: The global perspective of Human Rights and developments at regional level has been studied by using the domestic statutes, international covenants, conventional, etc. The doctrinal method of research has been adopted to achieve the objectives of the current study.

Implication: The study has disclosed that being signatory of UNO Conventions and Declarations, the Pakistan has been under obligation to incorporate International Human Rights into its legal system.
\end{abstract}

Findings: The study finds that Pakistan has taken into consideration the international developments on Human Rights and has enacted various laws accordingly to promote the fundamental liberties.

(C) 2021 The authors, under a Creative Commons Attribution-

NonCommercial 4.0

Recommended citation: Hussain, A., Saeed, M. A. and Mushtaq, S. A. (2021). Application of Human Rights Laws in Pakistan: A study with reference to International Bill of Human Rights. Journal of Business and Social Review in Emerging Economies, 7 (4), 963-976.

\section{Introduction}

Human Rights Law has become the most popular subject now a day. With the passage of time, people have become more aware about their rights. Everyone talks about the Human Rights situations and shows his displeasure regarding the violations of rights and freedoms. Due to information technology and education, people easily interact with one another and anything which happens at one side of the world instantly reaches the other side of the world. This has also created a challenge for the developing States to ensure the security of life, liberty and other rights of its citizens. The Human Rights developments at international level has further required the 
States to take serious steps at domestic level to protect the Human Rights of the people. Pakistan being member of the International community has also implemented the International Human Rights conventions and covenants into its legal system. The present paper explores the efforts of Pakistan regarding application of Human Rights Laws. At first, the research explains the main Human Rights declarations and covenants and then their incorporation into Pakistani laws has been described.

\section{What is International Human Rights Law?}

The International Human Rights Law (or IHRL) may be defined as that body of the law, which has been established to protect and promote the human's rights at global, regional and national/domestic level and which mainly consists of international human rights treaties and conventions. IHRL divides the human rights into the following two categories:

- Civil \& political rights, and

- Social, economic \& cultural rights.

The first category protects humans' freedom from intrusion by the State and makes sure that everybody would get a chance to contribute in the civil activities of the community. This category of rights includes, for example, the freedom of speech, freedom of assembly, protection from torture (Weller, 2019), etc.

The second category of rights protects the basic necessities of life, which includes the right to food and water, right to residence, and the right to adequate health facilities (Ibid.).

\section{The International Bill of Human Rights (IBHR)}

The loss of humanity in World Wars I \& II compelled the nations to re-think for international peace (Chowdhury, 2012). There is no doubt that Man is the most precious entity among all the beings of the Universe. It must be protected at all levels. The international struggle for scheming an IBHR started after the establishment of United Nations Organization on $24^{\text {th }}$ of October in 1945. First of all, the UN Charter envisioned the promotion of peace to protect humanity (Article 1). The next accomplishment was the framing and espousing the Universal Declaration of Human Rights (UDHR) in 1948 which complemented the UN Charter and offered a roadmap regarding the human rights (Weller, 2016). It is said that most of the nations framed their constitutions under inspiration of the UDHR (Ali, 2008). It also paved the way to serve the humanity by protecting human rights at regional levels, for instance, the European Convention on Human Rights (ECHR) in 1950 was designed for European community. The struggle continued and finally in 1966, the International Covenant on Economic, Social, and Cultural Rights (ICESCR) and the International Covenant on Civil and Political Rights (ICCPR) were framed. Later on, many other international covenants and conventions were introduced and adopted by the UN member States. It is pertinent to mention that current study is limited to the above said three documents (i.e., UDHR, ICESCR and ICCPR), and their Optional Protocols which are considered as the IBHR.

\section{The Scope of International Bill of Human Rights}

The idea of protecting Human Rights along with related concerns is not a modern thing. It is as old as the human himself is (Chowdhury, 2012). The history shows that disrespect to human rights resulted in unpleasant consequences including wars and genocides (Weller 2016). The same happened during the World Wars I and II. However, after the World War II, efforts started to protect the human rights which lead to the creation of the IBHR. The scope of each fragment of IBHR is discussed below.

(1) The Universal Declaration of Human Rights, 1948

By its resolution number 217 A (III) of $10^{\text {th }}$ of December 1948, the UN General Assembly 
adopted the UDHR whereby 48 States voted in its favor and none opposed it. The Declaration protects almost all the basic human rights. It has a preamble along with 30 Articles.

Article 1 of the Declaration explains the basic theme of the document, for example, the right to equality and liberty is human's inherent right which cannot be transferred or withdrawn. Similarly, the human being a moral and rational creature, is dissimilar from other beings on earth and, thus, deserves some rights which other beings cannot exercise. Article 2 provides for parity and non-discrimination in respect of exercise of human rights. The Article prohibits differences of all kinds. U/A 3, the Declaration asserts the right to life including safety and liberty of the humans. The right to life (also called the mother right of all the rest of the rights) is such a right which is necessary to enjoy all remining rights.

Articles 4-21 proclaim civil and political rights with freedom from enslavement and servitude, protection from torture, protection from inhuman behavior, right to recognition ubiquitously as a person under the law, right to legal relief through courts, prohibition from inhuman arrest or detention, right to fair and impartial trial in open by independent forums, right to nationality, asylum, religion, property, equal opportunities, etc.

Articles 22-27 recognize the social, economic and cultural rights, i.e., rights to work, social security, similar pay for similar work, rest and leisure, education, adequate living for good health and to take part in cultural activities.

Articles 28-30 provide that everybody has right to a conducive atmosphere where the abovementioned rights be fully enjoyed. Article 30 highlights that nobody would claim any right to involve in any bustle or to do anything to destroy any of the rights or freedoms enshrined in the Declaration.

Due to its worldwide character, the UDHR has been regarded as a package of essential rights for every human, and that's why it became a yardstick to gauge the amount of carre and progress regarding the universal human right standards (Glendon, 2004).

Since 1948, the UDHR not only has been a starting point for all the United Nations conventions and declarations, but also a primary source of motivation for domestic, regional and international efforts to protect and promote the human rights. It also conceived the path for all succeeding efforts in the domain of human rights. It has also given the key idea for other lawfully binding international covenants intended to guard the human rights and fundamental liberties which it declares (OHCHR, 1995).

Furthermore, the UDHR preserves its rationality for every human, irrespective of the fact that whether or not the States have properly accepted its principles. It has been observed that UDHR became the most translated text of the world that is available in more than 500 languages, which has influenced more than 200 documents since its inception. Although, the UDHR is not a legally enforceable document and it is mere a declaration, yet, it has become a part of the customary international law (Weller 2016), so, it may be said that the States are morally bound to implement the provisions of UDHR (Hannum, 1998).

\section{(2) International Covenant on Economic, Social, and Cultural Rights, 1966}

On $16^{\text {th }}$ of December, 1966, the United Nations adopted the ICESCR, however, it got binding force on $3^{\text {rd }}$ of January 1976. The ICESCR has 171 State parties whereby 71 are the signatories (UNTC, 2021). It was meant to protect the economic, cultural and social rights. This Covenant follows the scheme similar to the UDHR. It has a preamble and 31 Articles. 
Article 1 of this Covenant proclaims the freedom of self-determination for every human. This right is further extended to the right to one's political standing, right to follow one's cultural, social and economic goals, and the freedom to manage and dispose of one's own resources.

Articles 6-8 protect the labour rights including right to occupation, right to fair and decent wages, right to reasonable and favorable working atmosphere, right of equal opportunity and treatment at the workplace, right to paid holidays, right to leisure and rest, right to setup or join trade unions, right to strike, protection from discrimination at workplace, protection from forced labour, protection from child labour, etc.

Article 9 protects the social security rights. It obligates the State parties to provide social insurance schemes against the sickness, injury, disability, unemployment, maternity, old age, etc. It further obligates the State parties to support the orphans, patients, survivors, poor and needy.

Article 10 protects the right to establish family. It obligates the States to make sure that marriages are contracted with free consent of the parties. It includes right to paid leave or other necessary support to parents before/after child-birth. It also includes protection of children from social or economic exploitation and employing them into risky occupations.

Article 11 protects sufficient standard of life. It includes right to adequate quality foodstuff and clean water, housing, clothing, etc. in accordance with the surrounding culture. It obligates the State parties to eliminate hunger.

Article 12 saves the right to health (mental \& physical). It includes right to sanitation and nutrition, right to medical treatment, right to healthy environment, protection from medical experimentation, etc.

Articles 13-14 protect the education rights. This right is extended to free and compulsory education up to primary level without any discrimination, equal access to higher education, moral and religious education, scholarships, academic freedom of faculty and students, elimination of corporeal punishment, etc.

Article 15 protects the right to take part in cultural activities. It also includes the right to acknowledge intellectual work of authors. State parties are required to promote the scientific research and preserve the culture.

\section{The Optional Protocol of ICESCR}

Optional Protocol for extending the scope of ICESCR was espoused by the United Nations on $10^{\text {th }}$ of December 2008. It was offered for signatures on $24^{\text {th }}$ of September 2009. After receiving the essential ratifications, it came into force on $5^{\text {th }}$ of May 2013. It has been signed by 45 States and ratified by 24 States up to 2020. The Optional Protocol to the ICESCR is an extension of the Covenant that allows State to admit the jurisdiction of Human Rights Committee on Economic Social and Cultural Rights to deliberate individual complaints.

\section{(3) International Covenant on Civil and Political Rights, 1966}

On $19^{\text {th }}$ of December 1966, the United Nations adopted the ICCPR, however, it got force on $23^{\text {rd }}$ of March 1976. The ICCPR has 173 State parties, 75 by signature as well as ratification, while the rest by accession, or succession (UNTC, 2021). The purpose of the ICCPR was to protect the civil and political rights. The Covenant has recognized the inherent self-esteem of each human and assumes to promote human rights conditions at State level so that these rights become enjoyable. The ICCPR follows the scheme similar to the ICESCR and UDHR. It has a preamble 
followed by 53 Articles.

Article 1 of the Covenant proclaims the universality of the inherent right to self-determination. This Article requires the States to respect as well as promote the enjoyment of the said right. Article 2 confirms that freedoms protected by ICCPR would be exercised by every man and woman within the ratifying States.

Articles 6-8 protect the rights relating to physical integrity (i.e., right of life, protection from violence, protection from cruel or degrading or inhuman treatment including safety from slavery, etc.).

Articles 9-11 protect the rights relating to security and liberty of person (i.e., protection from arbitrary arrest and confinement, protection from pre-trial detention, right of prisoners/other detainees to dignified and humane treatment, etc.).

Articles 14-16 protect the rights relating to procedural fairness (i.e., right to justice and a fair treatment during trial which consists of equal attention before judge, right to be treated as innocent, right to hearing before an impartial, competent and independent tribunal, with a judgment announced publicly, right to prompt and detailed information in the language understandable by the litigant, right to reimbursement for victims of miscarriage of justice, right to speedy trial, right to counsel, right to face lesser punishment where criminal penalties have been altered between the time of offence and conviction. protection from selfincrimination, protection from double jeopardy, protection from prosecution by ex post facto law, protection from execution of retrospective punishment for committing offences, right to recognition as person before law, etc.).

Articles 12, 13, 17-24 and 27 protect the rights relating to individual liberties (i.e., right of privacy, protection from arbitrary expulsion of resident aliens, protection from provocative war and hate, freedom of movement, expression, religion, assembly and association, the right to marriage, right to name and nationality, and rights of linguistic, ethnic and religious minorities to celebrate their cultural, etc.).

Articles 3 and 26 protect the political rights (i.e., protection against discrimination and equality rights)

Article 28 provides to setup a Human Rights Committee which would be responsible to administer the execution of rights enumerated in the Covenant.

The States which ratified the convention are bound to preserve and protect the rights enshrined in the covenant. Such States may be compelled to adopt statutory, judicial and administrative measures to protect the said rights as well as to provide effective remedies (CCLA, 2015).

\section{Optional Protocols to ICCPR}

To give additional protection to Human Rights, two Optional Protocols to extend the scope of ICCPR have been designed. The First Optional Protocol sets up a complaint system for individuals, which allows them to file complaints before Human Rights Committee regarding violation of the provisions of the Covenant. This system has also widened the scope of the Covenant in respect of interpretation/application of ICCPR. First Optional Protocol has 116 State parties up to September 2019.

The Second Optional Protocol aimed to eradicate the penalty of death. In this regard, the States were allowed to put a reservation to award the penalty of death for the severe offences relating to 
military institution, might be committed during the wartime. This Protocol has 87 State parties up to September 2019.

\section{Conditions and Limitations}

The UDHR, U/A 29-30, states that exercise of rights and freedoms provided by the UDHR may be subject to certain limitations, imposed by law, to secure due acknowledgement of the human rights of others as well as to fulfil the fair needs of public order, morality, and welfare within the society. Rights cannot be exercised against the principles/purposes of the UNO, or to destroy any of the rights provided by the Declaration.

The ICESCR, U/A 4, provides that exercise of rights proclaimed by the Covenant may be restricted by the law, to promote the general welfare within the society.

Unlike the UDHR and the ICESCR, the ICCPR contains no special provision regarding authorizing the restrictions regarding enjoyment of human rights. However, certain Articles of the Covenant provide that the enjoyment of the said rights would be subject to law, public order, national security, or others' rights. Certain rights, thus, can never be limited or suspended, even in the emergency, i.e., freedom from torture, rights to life, protection against slavery/servitude, protection against operation of retrospective punitive laws, protection against detention for debts, right to recognition before the law as an individual, liberty of conscience, thought as well as religion (OHCHR, 1995).

The ICCPR U/A 4 also allows the State parties to avoid from their obligations mentioned in the Covenant for certain circumstances, i.e., during times of official public emergencies independent of any discrimination on the basis of race or colour or sex or language, or religion, or social background. Nevertheless, the States are not entitled to derogate from Articles 6-8, 11, 15-16 and 18. Such suspensions or limitations must be reported to United Nations.

\section{Implementation of International Human Rights Laws in Pakistan}

Being a party to International Human Rights Covenants, the Pakistan has accepted the following obligations:

1. to deference human rights;

2. to shield the exercise of human rights against violations; and

3. to enforce individuals' human rights, i.e., to adopt measures to provide an environment where the human rights would be fully exercised.

Before going towards the details regarding application of International Human Rights Laws in Pakistan, it is essential to understand the implementation scheme of the IBHR which is as follows:

Article 2(2) of ICCPR states that States are bound to take appropriate steps to enact such laws or adopt such measures which may help to recognize the rights under the Covenant. The States which have ratified the Covenant must take further steps to acknowledge the acceptance of Covenant.

In addition, Article 28 of ICCPR provides to setup a Human Rights Committee to monitor the State efforts to implement the Covenant. The States are bound to send reports after every five years to this Human Rights Committee to review the measures used by the States to adopt the human rights documented in the ICCPR.

The First Optional Protocol to ICCPR permits the sufferers (of human rights violation) to be heard by the Human Rights Committee. However, before filing the appeal to the Human Rights 
Committee, the pursuer must exhaust the domestic legal recourses (UFHR, 2008). Nevertheless, the ICCPR, U/A 41, also provides that a State party which asserts that another State is not taking steps to implement the ICCPR, may submit in writing the same to the Human Rights Committee for deliberation. Furthermore, non-governmental organizations (NGOs) may also contribute by reporting that the rights under the ICCPR are being protected or not, by sending shadow reports. They may also highlight certain areas to be considered by the Committee on Human Rights.

After the investigation, the Committee on Human Rights declares the findings which are of great value. If the Committee upholds the accusations, the State party will have to take necessary measures to address the reported abuse/s (UFHR, 2008).

\section{Implementation of UDHR in Pakistan}

It is observed that while framing many constitutions of the world, the UDHR has been followed as a model document with reference to human rights portion (Elkins, 2017). The scheme of Constitution of Pakistan of 1973 regarding fundamental rights also seems to be inspired by the UDHR (Robertson, 1996). The following table shows the influence of UDHR over the fundamental rights enshrined in the Pakistan Constitution of 1973:

Table 1.

\begin{tabular}{|l|l|l|}
\hline Sr. & $\begin{array}{l}\text { Rights provided by the Universal Declaration } \\
\text { of Human Rights, 1948 }\end{array}$ & $\begin{array}{l}\text { Rights enshrined in the Constitution of } \\
\text { Islamic Republic of Pakistan, 1973 }\end{array}$ \\
\hline 1 & U/A 3 Right to life or liberty or security & U/A 9 Security of person \\
\hline 2 & U/A 9 Freedom from arrest, detention, or exile & $\begin{array}{l}\text { U/A 10 Safeguards as to arrest and } \\
\text { detention }\end{array}$ \\
\hline 3 & U/A 10 Right to fair trial & U/A 10-A Right to fair trial \\
\hline 4 & U/A 4 Prohibition of slavery & U/A 11(1) Prohibition of Slavery \\
\hline 5 & $\begin{array}{l}\text { U/A 11(2) Protection against } \\
\text { retrospective punishment }\end{array}$ & $\begin{array}{l}\text { U/A 12 Protection against retrospective } \\
\text { Punishment }\end{array}$ \\
\hline 6 & $\begin{array}{l}\text { U/A 12 Freedom from arbitrary interference with } \\
\text { privacy }\end{array}$ & U/A 14(1) Right to privacy \\
\hline 7 & U/A 5 Prohibition of torture & U/A 14(2) Prohibition of torture \\
\hline 8 & U/A 13(1) Freedom of movement & U/A 15 Freedom of movement \\
\hline 9 & U/A 20(1) Freedom of Assembly & U/A 16 Freedom of Assembly \\
\hline 10 & U/A 20(1) Freedom of Association & U/A 17 Freedom of Association \\
\hline 11 & U/A 23(1) Right to work & $\begin{array}{l}\text { U/A 18 Freedom of trade, business or } \\
\text { Profession }\end{array}$ \\
\hline 12 & U/A 19 Freedom of opinion/expression & U/A 19 Freedom of speech \\
\hline 13 & U/A 18 Freedom of religion & U/A 20 Freedom of religion \\
\hline 14 & U/A 17 Right to property & U/A 23-24 Right to property \\
\hline 15 & U/A 7 Right to equality & U/A 25 Equality of citizens \\
\hline 16 & U/A 26 Right to education & U/A 25-A Right to education \\
\hline 17 & $\begin{array}{l}\text { U/A 21(2) Right to equality regarding access to } \\
\text { public service }\end{array}$ & $\begin{array}{l}\text { U/A 27 Safeguard against discrimination } \\
\text { regarding services }\end{array}$ \\
\hline 18 & 27(1) Right to take part in cultural life & $\begin{array}{l}\text { U/A 28 Preserving of culture, or script or } \\
\text { language }\end{array}$ \\
\hline
\end{tabular}

The following table shows a few other rights enshrined in the UDHR which are also provided by the Pakistan Constitution:

Table 2.

\begin{tabular}{|l|l|l|}
\hline Sr. & $\begin{array}{l}\text { Rights provided by the Universal Declaration } \\
\text { of Human Rights, 1948 }\end{array}$ & $\begin{array}{l}\text { Rights enshrined in the Constitution of } \\
\text { Islamic Republic of Pakistan, 1973 }\end{array}$ \\
\hline 1 & U/A 8 Right to enforce human rights & $\begin{array}{l}\text { U/A 184(3) and 199(1) Right to enforce } \\
\text { fundamental rights by the Supreme Court } \\
\text { and High Courts respectively }\end{array}$ \\
\hline 2 & U/A 16 Right to marriage & U/S 35 Protection of family \\
\hline 3 & U/A 21(3) Right to vote & U/A 51 Right to vote \\
\hline
\end{tabular}




\begin{tabular}{|l|l|l|}
\hline 4 & U/A 21(1) Right to contest elections & U/A 62 Right to contest election \\
\hline 5 & U/A 22 Social security rights & \multirow{2}{*}{ U/A 27-A(1) Social security rights, etc. }
\end{tabular}

The above-mentioned information shows the influence of UDHR. However, the following human rights as provided by the UDHR have not become part of the fundamental rights in the Pakistan Constitution:

a) Right to recognition before the law U/A 6

b) Presumption of innocence U/A 11

c) Right to asylum U/A 14

d) Right to nationality U/A 15

e) Right to Leisure and rest U/A 24

f) Right to Free and fair world U/A 28

It must not be inferred from the above list that these rights are not available in Pakistan. Most of the rights from the above list are available impliedly which are exercised and are never denied at any forum, for example, right to recognition before the law, right to nationality, presumption of innocence, etc.

On the basis of above-mentioned fundamental rights under the Constitution of Pakistan, the victims/sufferers of human rights violations apply to the higher courts for legal reliefs by filing writ petitions. The courts have been awarding appropriate remedies accordingly.

\section{Implementation of ICESCR in Pakistan}

The Pakistan has signed the ICESCR on 3rd of November 2004 while ratified $^{1}$ it on $17^{\text {th }}$ of April 2008. However, Pakistan has refused to sign the Optional Protocol to the ICESCR regarding acceptance of individual complaints procedures and Inquiry Procedure (UFHR, 2008). It has a reservation to interpret the ICESCR in accordance with its own Constitution. However, the provisions of ICESCR are legally binding on Pakistan. The following table shows the implementation of the Covenant in Pakistan:

\begin{tabular}{|l|l|l|}
\hline Sr. & Rights provided by the ICESCR, 1966 & Position in Pakistan \\
\hline 1 & U/A 01 Self-determination & $\begin{array}{l}\text { Though not codified expressly, yet this right is } \\
\text { exercised in Pakistan. It may be said that this } \\
\text { right has been recognized impliedly. This right is } \\
\text { never denied under any law. People are free to } \\
\text { decide their political affiliations. They may } \\
\text { decide their social, economic and cultural goals }\end{array}$ \\
\hline 2 & U/A 13-14 Education & $\begin{array}{l}\text { This right is recognized U/A 25-A and 37(a), } \\
37 \text { (b) and 37(c) of the Pakistan Constitution of } \\
1973\end{array}$ \\
\hline 3 & U/A 06-08 Labour rights & $\begin{array}{l}\text { These rights are recognized U/A 11, 17, 18, } \\
\mathbf{2 5} \text { and 37 (e) of the Pakistan Constitution of } \\
1973 \text {. Article 11 protects against child labour and } \\
\text { bonded labour of any type. Article 17 protects } \\
\text { freedom of association and union. Article 18 } \\
\text { without any discrimination, allows to enter any } \\
\text { legitimate occupation or business. Article 37(e) } \\
\text { provides for just and humane conditions of work } \\
\text { and } \\
\text { that women and children must not be employed } \\
\text { in the vocations not suitable to their sex/age, and } \\
\text { it also provides for maternity benefits for } \\
\text { working ladies. The labour laws of Pakistan also } \\
\text { protect the labour rights, i.e., the Workmen's }\end{array}$ \\
\hline
\end{tabular}

${ }^{1}$ The ICESCR was ratified by the President Pervez Musharraf. 


\begin{tabular}{|c|c|c|}
\hline & & $\begin{array}{l}\text { Compensation Act 1923, the Factories Act 1934, } \\
\text { the Payment of Wages Act 1936, the Minimum } \\
\text { Wages Ordinance 1961, the Industrial \& } \\
\text { Commercial Employment (standing orders) } \\
\text { Ordinance 1968, the Shops and Establishment } \\
\text { Ordinance 1969, the Employment of Children } \\
\text { Act (ECA), 1991, the Bonded Labour System } \\
\text { (Abolition) Act 1992, the Protection against } \\
\text { Harassment of Women at Workplace Act 2010, } \\
\text { the Industrial Relations Act 2012, etc. }\end{array}$ \\
\hline 4 & U/A 09 Social security & $\begin{array}{l}\text { In Pakistan, social security rights are protected } \\
\text { under the Provincial Employees' Social Security } \\
\text { Ordinance 1965, the Sindh Employees' Social } \\
\text { Security Institution 1970, Compulsory Group } \\
\text { Insurance Scheme 1968. Different social support } \\
\text { programs via Bait-ul-Maal are also doing the } \\
\text { needful. The Employees Old Age Benefits } \\
\text { Institution and the Employees Social Security } \\
\text { Institution are also playing their role to support } \\
\text { the employees. The Punjab Employees' Social } \\
\text { Security Institution is another recent } \\
\text { development. Social security rights are also } \\
\text { protected U/A 27-A(1) of the Pakistan } \\
\text { Constitution 1973. }\end{array}$ \\
\hline 5 & U/A 10 Family & $\begin{array}{l}\text { U/S } 35 \text { of the Pakistan Constitution 1973, family } \\
\text { rights are protected. Right to maintenance and } \\
\text { dower of wife is protected by the Muslim Family } \\
\text { Laws Ordinance } 1961 \text {. Right to maintenance of } \\
\text { parents, wife and children is also protected U/S } \\
125 \text { of the Criminal Procedure Code. }\end{array}$ \\
\hline 6 & U/A 11 Basic necessities & $\begin{array}{l}\text { Most of the basic necessities are covered U/A } 9 \\
\text { of the Pakistan Constitution 1973. The scope of } \\
\text { right to life has been extended by the decisions of } \\
\text { the superior courts. Basic necessities are also } \\
\text { protected U/A 27-A(2) of the Pakistan } \\
\text { Constitution 1973. The National Zero Hunger } \\
\text { Action Plan and Pakistan Vision } 2025 \text { are may be } \\
\text { regarded as notable efforts in this respect. }\end{array}$ \\
\hline 7 & U/A 12 Health and Environment & $\begin{array}{l}\text { Health rights are also protected U/A 27-A(2) of } \\
\text { the Pakistan Constitution 1973. Environment } \\
\text { rights are covered U/A } 9 \text { of the Pakistan } \\
\text { Constitution } 1973 \text { as it is interpreted in the case } \\
\text { of Shehla Zia v. Wapda, PLD } 1994 \text { SC } 693 \text {. }\end{array}$ \\
\hline 8 & U/A 15 Culture & $\begin{array}{l}\text { Cultural rights are protected U/A } 28 \text { of the } \\
\text { Pakistan Constitution } 1973 \text {. }\end{array}$ \\
\hline
\end{tabular}

The above-mentioned information shows the incorporation of ICESCR into Pakistani laws.

\section{Implementation of ICCPR in Pakistan}

The Pakistan has also signed the ICCPR on $17^{\text {th }}$ of April 2008 while ratified ${ }^{2}$ it on 23rd of June 2010. But it has neither signed the Optional Protocol 1 (regarding acceptance of complaints procedures for individuals) nor the Optional Protocol 2 (which is designed to abolish death penalty) to the ICCPR (OHCHR, 1996). However, the provisions of ICCPR are legally binding on Pakistan. The following table shows the integration of the Covenant into the Pakistan Constitution of 1973:

Table 4.

\begin{tabular}{|l|l|l|}
\hline Sr. & Rights provided by the ICCPR, 1966 & Rights under Pakistan Constitution \\
\hline
\end{tabular}

\footnotetext{
${ }^{2}$ The ICCPR was ratified by the President Asif Ali Zardari.
} 


\begin{tabular}{|l|l|l|}
\hline 1 & U/A 6 Right to life & U/A 9 Right to life \\
\hline 2 & U/A 7 Protection against torture & U/A 14(2) Protection against torture \\
\hline 3 & U/A 8 Protection against slavery & U/A 11(1) Protection against slavery \\
\hline 4 & U/A 9 Right to security/liberty of person & U/A 9 Security of person \\
\hline 5 & U/A 12 Freedom of movement/residence & U/A 15 Freedom of movement \\
\hline 6 & U/A 14 Right to fair trial & U/A 10-A Right to fair trial \\
\hline 7 & $\begin{array}{l}\text { U/A 15 Protection against } \\
\text { retrospective punishment }\end{array}$ & $\begin{array}{l}\text { U/A 12 Protection against retrospective } \\
\text { Punishment }\end{array}$ \\
\hline 8 & U/A 18 Freedom of religion & U/A 20 Freedom of religion \\
\hline 9 & U/A 19 Right to hold views without intrusion & U/A 19 Freedom of speech \\
\hline 10 & U/A 21 Right of peaceful assembly & U/A 16 Freedom of Assembly \\
\hline 11 & U/A 22 Freedom of Association & U/A 17 Freedom of Association \\
\hline & U/A 23 Right to marriage & U/A 35 Protection of family \\
\hline & U/A 24 Children's rights & $\begin{array}{l}\text { Children rights are protected U/A 11 (3), 25(3), } \\
\text { U/A 25-A, 26(2), 35, 37(e) }\end{array}$ \\
\hline 12 & U/A 25 Political rights & U/A 51 \& 62 Political rights \\
\hline 13 & U/A 26 Equality before law & U/A 25 Equality of citizens \\
\hline & U/A 27 Minority's rights & U/A 36 Minority's rights \\
\hline
\end{tabular}

The above table shows the impact of ICCPR over the Constitution. The following human rights have not been included in the Constitution of Pakistan, 1973, however, a most of these are protected by other laws in Pakistan:

U/A 10 Detainees' Rights

U/A 11 Right to not be detained merely for breach of contract

U/A 13 Aliens' rights

U/A 16 Right to recognition before the law as a person

U/A 17 Protection against arbitrary/unlawful interference

\section{Reservations}

The Pakistan, initially, made the following reservations regarding the ICCPR:

(1) that Articles 3, 6-7 and 18-19 of the Covenant would be applied in conformity with the provisions of the Pakistan Constitution of and laws of the Shariah;

(2) that Article 12 of the Covenant would be applied in conformism with the provisions of the Pakistan Constitution;

(3) that regarding Article 13 of the Covenant, the Government of Pakistan reserves the right to apply Pakistani laws in respect of the foreigners;

(4) that Article 25 of the Covenant would be applied in conformity with the provisions of the Pakistan Constitution; and

(5) that the Government of Pakistan does not accept the jurisdiction of Human Rights Committee as mentioned U/A 40 of the ICCPR.

However, later, the Pakistan removed its reservation regarding Articles 6-7,12-13,18-19 and 40 of the ICCPR. It modified the reservations regarding Articles 3 and 25 as follows:

a) That Article 3 of the ICCPR would be applicable in conformity with the personal laws of the citizens as well as the Qanoon-e-Shahadat.

b) That Article 25 of the ICCPR would be applicable in conformity with Articles 41(2) and 91(1) of the Pakistan Constitution 1973.

With reference to ICESCR, the Pakistan, initially declared that its provisions would be implemented in a progressive way subject to the development plans and economic position of the State. The other declaration was that the Covenant would be implemented in compatibility with the principles laid down in the Pakistan Constitution 1973.

Later, the Pakistan modified its declaration into the reservation by stating that to exercise the 
rights enshrined in the Covenant in the best possible way, all the reasonable means would be used up to the maximum of its existing resources.

\section{Challenges in Implementation}

Now, we see a number of issues which have become challenges for implementing the certain provisions of the Covenants in Pakistan.

1. With reference to Right to marry U/A 23 of the ICCPR (which is also provided U/A 16 of the UDHR), the Pakistan has recorded no reservation. Due to this omission, implementation on Article 23 of the ICCPR has become a challenge because the Covenant allows marriages between men and women irrespective of their faith. Under the Islamic law, a Muslim man can marry a Muslim woman, or a woman of Christian or Jewish faith. All the other women are not qualified to become brides of Muslim men. Similarly, a Muslim woman cannot marry a non-Muslim person.

The Article 23 of the ICCPR restricts the marriage only between marriageable couples, i.e., the persons having the age of majority and sound mind, while under the Islamic law, marriage of young children is also recognized which is subject to the confirmation by the spouses (mostly by the wife) on attaining the age of majority.

2. The Pakistan has made no reservation in respect of right to equality U/A 26 of the ICCPR (which is also provided U/A 7 of the UDHR). The Covenant proclaims that man and woman shall have equal rights as to property. The result is that there becomes a contradiction between Article 26 of the ICCPR and the principles of Islamic law as to inheritance. When equal male and female legal heirs are entitled to their share in the estate, the share of female is half of the share of the male. For example, where there is one son and one daughter of the Muslim deceased, the share of daughter is one-third (1/3) while the share of son is two-third (2/3), which apparently seems injustice, but it is not in fact. And the reason is that every Muslim male is bound to provide maintenance to the female dependents of his family and this obligation is permanent. A Muslim male maintains his wife, mother, sisters and daughters and even other female relations too, if he has sufficient income, but a female is not bound to maintain her male relations.

Similarly, a Muslim male can contract up to four marriages at a time, but a Muslim female can contract only one marriage at a time.

Likewise, a Muslim male can dissolve the marriage by pronouncing Talaq, while a Muslim female cannot do so.

Thus, in several matters, treating both male and female equally, becomes impossible.

3. U/A 18 of ICCPR, the right to profess religion has been recognized. Under this provision, a person may change his religion any time, but under the Islamic Law, a Muslim cannot renounce his religion otherwise he would be punished for committing apostacy. It means that a reservation to this effect would have been recorded to avoid this conflict.

\section{Conclusion}

The International Bill of Human Rights deserves to be treated as a great achievement in the history of human rights. In Pakistan, the current theoretical framework of its legal system contains sufficient laws for the protection of human rights. The Constitution of Pakistan incorporates more than $75 \%$ of the provisions of the International Human Rights Covenants. The rest of the provisions (except a few) are also protected by other laws of the land. However, the implementation of these laws is not up to the mark. There is need to educate the society about its 
fundamental human rights which are protected by the laws. With education, people get awareness and confidence which motivate and encourage the public to stand for their rights. In Pakistan, although the process of awareness has started but it needs to be accelerated which is possible when all the sections of the society would put their efforts together. There are, no doubt, challenges in implementing certain provisions of International human rights which may be addressed by taking into confidence all the concerned stakeholders of the society.

\section{References}

Ahmed, A., Chhijan, H. B., \& Bhutto, H. (2019). Critical analysis of various issues regarding honour killing in Pakistan in general and in Sindh in particular. Al-Aijāz Research Journal of Islamic Studies \& Humanities, 3(1), 406-414.

Ali, S. S. (2008). Disability, human rights and redistributive justice: Some reflections from the North

West Frontier Province of Pakistan on popular perceptions of disabled people. In (pp. 110-126). Routledge.

Arat, Z. F. K. (2006). Forging a global culture of human rights: Origins and prospects of the international bill of rights. Human Rights Quarterly, 416-437.

Arif, M., \& Khan, M. B. (2019). Implementation of International Covenant on Civil and Political Rights Pursuant to its Article 3: A Case Study of Tribal Area, District Dera Ghazi khan, Pakistan. Pakistan Journal of Social Sciences (PJSS), 39(4).

Ben-Natan, S. (2017). Constitutional mindset: the interrelations between constitutional law and international law in the extraterritorial application of human rights. Israel Law Review, 50(2), 139-176.

CCLA. (2015). Summary: International Covenant On Civil And Political Rights (ICCPR). Retrieved November 2, 2021 from https://ccla.org/privacy/surveillance-andprivacy/summary-international-covenant-on-civil-and-political-rights-

iccpr/\#: :text=The\%20United $\% 20$ Nations $\% 20$ International $\% 20$ Covenant,force $\% 20 \mathrm{on} \% 2$ 0March\%2023\%2C\%201976.

Chowdhury, A. R., \& Bhuiyan, J. H. (2012). An Introduction to International Human Rights Law. Brill. https://books.google.com.pk/books?id=iAkFLgEACAAJ

Clements, L., \& Read, J. (2008). Disabled People and the Right to Life: The Protection and Violation of Disabled People's Most Basic Human Rights. Taylor \& Francis. https://books.google.com.pk/books?id=adt9AgAAQBAJ

Elkins, Z., Ginsburg, T., \& Melton, J. (2017). Imagining a world without the Universal Declaration of Human Rights. Available at SSRN 2469194.

Glendon, M. A. (2004). The Rule of Law in the Universal Declaration of Human Rights, . Journal of Human Rights, 2(1). https://scholarlycommons.law.northwestern.edu/cgi/viewcontent.cgi?article=1008\&conte $\mathrm{xt}=\mathrm{njihr}$

Hannum, H. (1998). The UDHR in National and International Law. Health and Human Rights, 3(2), 144-158. https://doi.org/10.2307/4065305

Hayat, A. (2020). Labour rights in Pakistan. Retrieved June 14, 2020 from https://www.thenews.com.pk/print/672372-labour-rights-in-

pakistan\#: :text=The\%20Constitution\%20of\%20Pakistan\%20has\%20a\%20wide\%20rang e,discrimination $\% 20$ and $\% 20$ secure $\% 20$ humane $\% 20$ and $\% 20$ reasonable $\% 20$ working\%20c onditions.

Iyer, M., \& Jha, J. (2016). Reflection of ICCPR on South Asian Constitutions. Retrieved November 2, 2021 from https://nepalforeignaffairs.com/reflection-of-iccpr-on-southasian-constitutions/

Khan, A. A. (2017). Marrying Without the Consent of the Wali (a Case Study of Pakistan) Compatibility of Pakistani Family Laws with UDHR Retrieved November 1, 2021 from https://papers.ssrn.com/sol3/papers.cfm?abstract_id=3067457 
Mulunch, Y. A. (2010). The Relevance of the Universal Declaration of Human Rights Today: Appraisal Based on Its Significance and Some Contemporary World Realities. Jimma UJL, 3, 118.

Nadeem, M., \& Ahmad, I. (2016). An Analysis of the International Covenant on Civil and Political Rights Minimum Standards and Pakistan Anti-Terrorism Laws. JL \& Soc'y, 47, 1.

OHCHR. (1995). Fact Sheet No.2 (Rev.1), The International Bill of Human Rights https://www.ohchr.org/documents/publications/factsheet2rev.1en.pdf

OHCHR. (1996). Ratification Status for https://tbinternet.ohchr.org/_layouts/15/TreatyBodyExternal/Treaty.aspx?CountryID=131 \&Lang $=\mathrm{EN}$

Rashid, Q. (2011). Pakistan's Failed Commitment: How Pakistan's Institutionalized Persecution of the Ahmadiyya Muslim Community Violates the International Covenant on Civil and Political Rights. Rich. J. Global L. \& Bus., 11, 1.

Raza, H. (2020). Enforceability of Human Rights Against Private Entities in Pakistan. Retrieved October 31, 2021 from https://leappakistan.com/enforceability-of-human-rights-againstprivate-entities-in-pakistan/

Robertson, A. H., \& Merrills, J. G. (1996). Human Rights in the World: An Introduction to the Study of the International Protection of Human Rights. Manchester University Press. https://books.google.com.pk/books?id=8c26leVM4G8C

Shelton, D. L. (2020). Advanced Introduction to International Human Rights Law: 2nd edition. Edward Elgar Publishing. https://books.google.com.pk/books?id=-sgBEAAAQBAJ

u Din, N., \& Jacob, P. (2019). Challenges in Exercising Religious Freedom in Pakistan.

UFHR. (2008). International Bill of human Rights. Retrieved November 3, 2021 from https://www.humanrights.com/what-are-human-rights/international-human-rightslaw/international-human-rights-law-continued.html

UNTC. (2021). International Covenant on Civil and Political Rights. Retrieved November 3, 2021 from https://treaties.un.org/Pages/ViewDetails.aspx?src=TREATY\&mtdsg_no=IV$4 \&$ chapter $=4 \&$ clang $=\_$en

UNTC. (2021). International Covenant on Economic, Social and Cultural Rights. Retrieved

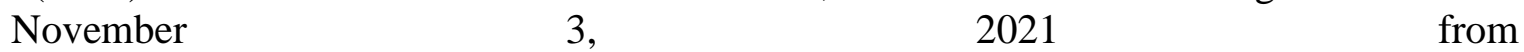
https://treaties.un.org/Pages/ViewDetails.aspx?src=IND\&mtdsg_no=IV$3 \&$ chapter $=4 \&$ clang $=\_$en

Watt, E. (2017). The role of international human rights law in the protection of online privacy in the age of surveillance. 2017 9th International Conference on Cyber Conflict (CyCon),

Weller, K. (2016). What is the Universal Declaration of Human Rights? Retrieved October 31, 2021 from https://www.coalitionfortheicc.org/news/20160930/what-universaldeclaration-human-rights

Weller, K. (2019). What is the International Covenant on Economic, Social and Cultural Rights? Retrieved November 3, 2021 from https://eachother.org.uk/what-is-the-internationalcovenant-on-economic-social-and-cultural-rights/ 